\title{
Industrialization and its Impact on Sweeping the Authority of Traditional Forms in Architecture
}

\section{(Study on human needs)}

\author{
Basim Hasan Al-Majidi ${ }^{1}$, Sara Raed Majeed ${ }^{2}$ Nairy Mugardich Krikor ${ }^{3}$ \\ ${ }^{1,2,3}$ Department Of Architecture, University of Technology, Baghdad, Iraq \\ **Corresponding author90004@uotechnology.edu.iq,90004@uotechnology.edu.iq, nano_arc@yahoo.com
} Submitted: $17 / 5 / 2017$

Accepted: $8 / 8 / 2018$

\begin{abstract}
Mankind is currently living in the age of industrialization and development in all its forms and manifestations because of its effects in all everyday life. This is because the technology has left a clear impact on human thoughts in general and architectural thoughts in particular. As the architecture is the embodiment of the thought of society that was produced, so the architecture must also be affected. This can be seen in the transition from the stone building and the limited narrow spaces to New Horizons across time. Thus the obvious diversity of forms, the widening of spaces and their sequencing in unlimited forms With the advent of the Industrial Revolution At the beginning of the twentieth century, its invasion of the world and its profound influence in various fields and among the architecture has reduced the focus on traditional forms design language and fantasy became more realistic by using computer modeling, its impact on architecture swept through the new forms of industrialization and the folding of cognitive and spatial distances, thus demonstrating uniqueness, creativity and expressing the self-identity and the time features that . It was born, from here the problem of research has arisen, which provides for "inadequate knowledge about the role of industrialization and mass production and its impact on producing Architectural forms that are unique, creative. This corresponds to the changes in human need but in contrary to the classical architecture language that came from. The research follows a series of actions to solve the research problem after the formula of the research hypothesis became as "The process of manufacturing and digital production affects the process of producing architectural forms positively or passively depending on nature, function, and the extent of repetition of the project". The most important conclusions and recommendations that demonstrated the architects quest to take advantage of all the possibilities of industrialization and the short-time production and increase the creative imagination of the designer with regard to architectural design is to create new languages and vocabulary for the architectural formation that is suited to the spirit of the times, and the pattern of existing buildings and installations of all types and functions, and the way they perform these various functions, is changed.
\end{abstract}

Key words: manufacturing, traditional forms, modeling and digital manufacturing, evolving human needs

\section{INTRODUCTION}

Undoubtedly, technological development has a significant impact on the expansion of the design capabilities of architecture engineers by strengthening the capacities to generate the shapes (curved or flat) and highly configurable, which could not have been able to generate, produce or even to implement by traditional customary methods and therefore to adopt technology in its work and the concept of industrialization has emerged in architecture as a contemporary concept since the advent of modern architecture in the early twentieth century and the emergence of mass production concepts in that period and the reflection on architectures that followed, and despite the emergence of a number of arguments that tried to explain and clarify it in architecture field, they did not give the concept a comprehensive definition or in-depth understanding, hence (The concept of manufacturing and mass production in the field of architecture as a general framework) emerged, then understand its concept through exploring and investigating range of selected studies. The research problem has been formulated as "inadequate knowledge about the role of industrialization and mass production and its impact on producing Architectural forms that are unique, creative and correspond to the changes of human need and are contrary to the classical architecture language from which they were born and sweep the power of traditional forms in architecture.

1-1 - Reserch Objective: "to build a knowledge framework about the industrialization and mass production and its impact on producing Architectural forms that are unique, creative and correspond to the changes of human need and are contrary to the classical architecture language from which they were born".

1-2 - Research Hypothesis: "there is an impact on the process of manufacturing and digital production on producing the architectural forms in a positive or negative manner depending on nature, function, and the extent of repetition of the project".

1-3 - Research purpose: Changing the prevailing view that the process of manufacturing and mass production leads to loss of identity due to repetition of the same forms or using forms contrary to that used within the vernacular environment. 
2- BUILDING THE THEORETICAL FRAMEWORK

\subsection{Philosophy of form:}

The Form was linguistically defined by Ibn Manthur as: "likeness and ideals, plural shapes and shape and form the thing: conceived, shaped: Photo" (16). The study of brothers Al Safa for Shapes $(21, \mathrm{p} 12)$ It is the famous sayings of the brothers Al Safa: : "know my brother, that studying the reasoning behind geometry leads to know-how and experience in all applied arts", and from points that indicate studies in this field are referencing the origin of things and starting from the beginning of the introduction and derivation, and activities in analyzing the complex formations that we inherited from the ancestors, starting from the point as what was abstract in the void and what Its movement is generated by the formation of the circle, which is the origin of the basic geometric shapes, the square consists of four circles as the triangle consists of three circuit centers and so on $(6, \mathrm{p} 35)$. As well as the influences of East Asian thought on the other hand where the Chinese philosophy and that depend return to the original geometric and natural principles in explaining the physical products and where the origin of the four things water, and air, fire and dirt is a philosophy that is identical to the philosophy of the Al Safa brothers who considered the number four as an important reference in their philosophy. The four sides have four seasons and the is ides of the geometric shapes from which the other four are derived, so the square has formed the basis of their concepts engineering, so most engineering outputs in the architecture begin with the rotation of the square around itself to produce the octagon and other polygonal shapes (14,p7), It is noted that similar examples are the traditional geometric formations themselves by looking at them within the concrete space. The point crystallizes into the straight line that becomes small as part of the circle and thus to the curved arc line which crystallizes and the surface of the surface forms the inert surfaces which are outputs to form a surface

2-2 Architectural form and human needs:

2.2.1 Hierarchy of Needs or Maslow's Hierarchy of Needs Or The Maslow Pyramid:

It's a psychological theory presented by the world of Maslo discusses the order of human needs and describes the motives that drive it; These requirements are summarized in figures no.1(5,p5):

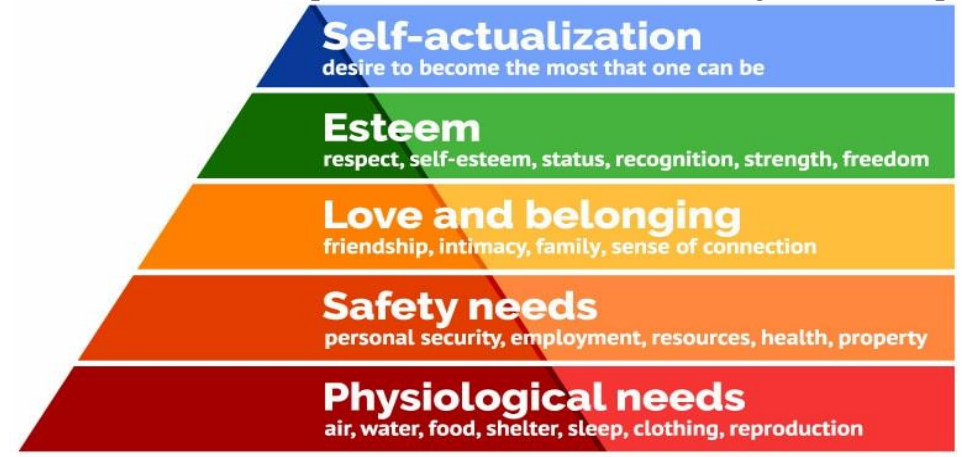

(figures No.1) Maslow's hierarchy of needs (7)

So we note that architecture is a reflection of needs in figures no. 2:

Physiological need $\longrightarrow$ The cave
Safety needs $\longrightarrow$ Primitive housing
Social needs $\longrightarrow$ Residential Communities
Need a sense of self $\longrightarrow$ Modern architecture
Need a sense of self $\longrightarrow$ Digital architecture

${ }^{1}$ Brothers al-Safa and Khalan al-Wafa are a group of Saranese Arab Muslim philosophers of the fourth century AH or 11th century $A D$, who tried to reconcile the Islamic beliefs and philosophical facts known in those days. 
The base of the pyramid is the Primitive (cave) dwelling that the human being has resorted to achieve safety and protection for survival life but with the evolution of societies and the stability of the security aspect the human start tends to achieve social need so he used to build villages and cities to have a sense of belonging to the group finally after satisfying basic needs resorted to the need for self-realization and distinguish and compete between societies that have been sacrificed through the distinctive and creative architecture that man has achieved(15,p36)

2-3 Classification of Traditional Forms :

2-2-1 Traditional geometric forms: The studies presented several classifications of traditional forms, the most important of which are as shown below:

-The first set of straight pieces such as squares, triangles, pistols, cubes, and other polygons.

-The second group of circular lines such as circular, oval, ring, macroscopic and others.

- The third group of non-circular curved lines such as helical and missing pieces. There are also geometric shapes composed of several geometric forms $(9, \mathrm{p} 23)$.
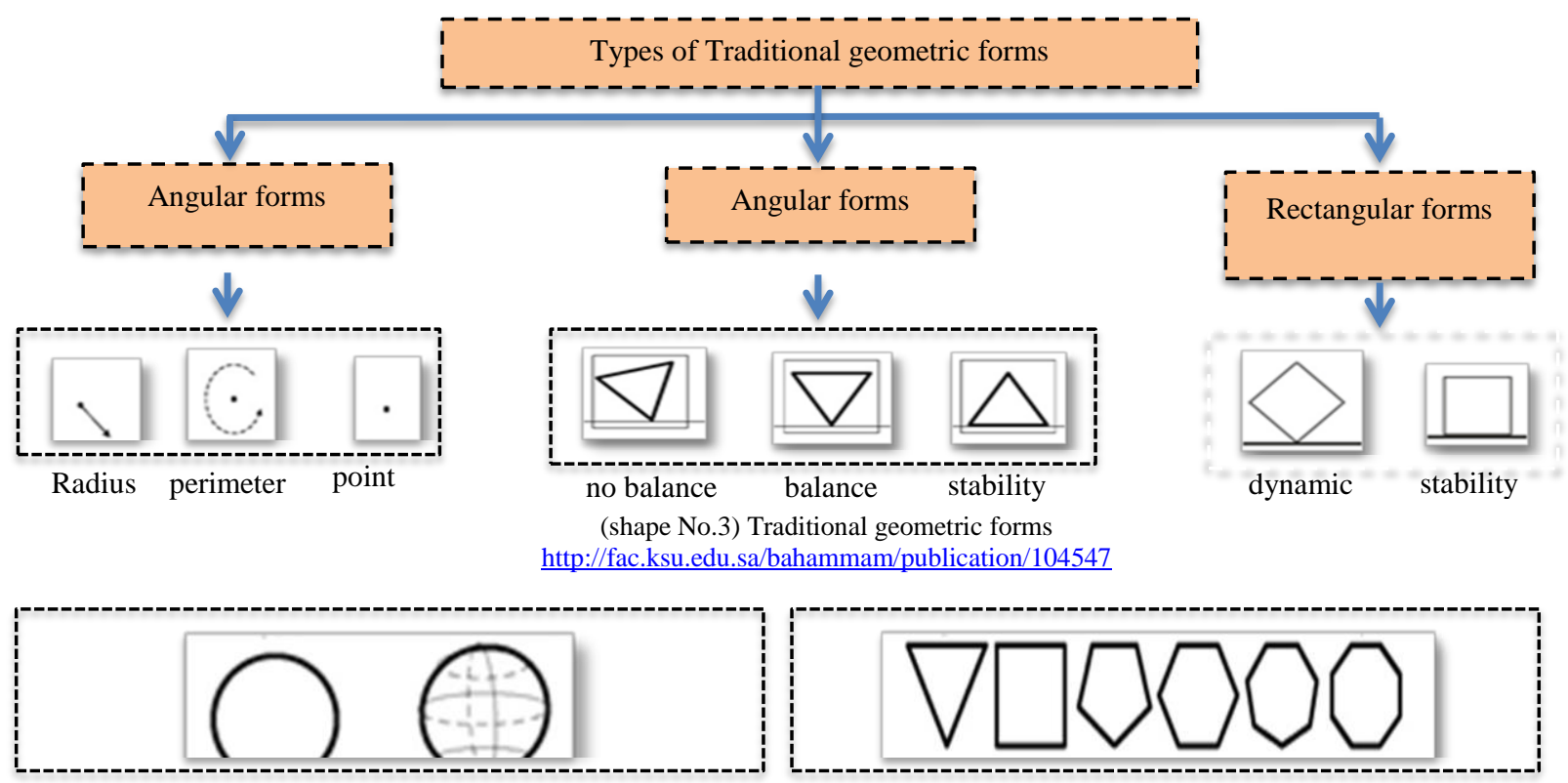

Geometric forms with circular lines

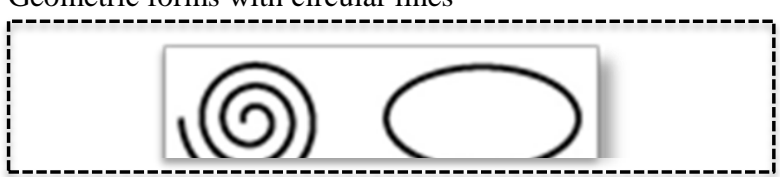

Geometric forms with curved lines

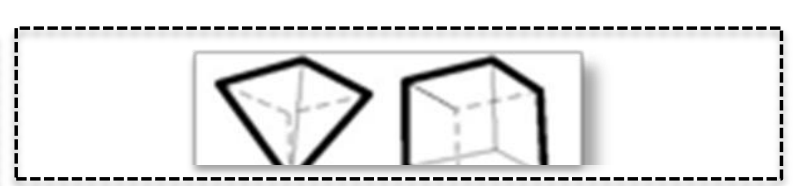

Geometric forms with straight segments

Types of geometric forms (shape No.4)

\subsubsection{Platonic solid forms:}

http://fac.ksu.edu.sa/bahammam/publication/104547

Ancient Greeks defined these models as Plato in one of his writings (Timaeus) and as is known when the Greeks the basic elements are the fire of the Earth water and air. Plato tied the regular pyramid with the element of fire and Cube to the earth element, with 20 faces in water and eight regular faces in the air The Dodecahedron are tied to the materials that make up the towers, the stars and the heavens, and the inhabitants of Scotland in the Stone Age discovered these statues thousands of years ago, where they found examples of these stone models. From that age, these polyphonic worlds in our three-dimensional world, what about them in other dimensions (27,p16). Schläfli has proven a Swiss athlete specializing in engineering and nodal analysis that there are only six regular forms with platonic characteristics in four dimensions, And only three shapes in five dimensions and more, other athletes have subsequently reached independently similar results, such as the athlete Stringam (30) Platonic models (also called regular or regular surfaces) are convex polyphonic forms with identical faces and each face is a convex regular polygon, and there are five types of these polyphonic shapes:

1. Cube.

2. Dodecahedron.

3. Icosahedron

4. Octahedron.

5. Tetrahedron $(2, \mathrm{p} 20)$

2.4 The Authority Of Traditional Forms And Their Dominance in Architecture:

The existence of traditional geometric shapes (square-triangle-circle) and the resultant and Platonic forms have had the obvious effect in the creation of architecture in its various eras and the era of industrial revolution has dominated these forms and for long decades of architectural formation. The designer has not been able to create new forms without reference to these traditional basic forms This is because it does not have the modern tools, mechanisms or techniques that help it to produce new forms, so that all the old ones remain under the authority of these traditional 
forms, $(8, p 4)$ After the era of the industrial revolution and the advent of modern technology, the focus becomes less on the language of the design of shapes that depends on the traditional way of producing shapes., herefore, the imagination in the production of shapes becomes more realistic by using the computer. The open method of discussion and dynamic and changing solutions the time of the digital revolution and its influence on the production of architectural form were occupied by these new forms of manufacturing processes.

All classical shapes that were dominant and authoritarian in the form of the various previous eras (9,p16), well they have produced a modern and sophisticated architectural designer means to implement these complex forms that have previously been difficult to implement, manufacturing processes for modern structural materials and the emergence of advanced technological materials such as smart materials, nanomaterials and nanotechnology, digital technology and computing tools are all contributing factors to the process of manufacturing the power of traditional forms of architecture (11,p23), The foregoing proposition has shown that Platonic shapes have been determined gradually as technology and industrialization evolve in addition to the rapidly changing times that have created alternatives to design and implementation methods. Contemporary and accompanied by a change in the intellectual concepts of all segments of society including the architects of the design concepts and the reflection on the patterns stored in the memory of the designer and receive.

3- MANUFACTURING AND QUANTITATIVE PRODUCTION:

3.1 Linguistic And Terminological Concept Of The Manufacturing:

Make: Make any dowry in the making, it is made (17) Al- Ferruzzi says that : manufacturing represents the process of changing the form or Status of the material to create a product or increase its benefit to man through the processes of production of various types where the conversion of primary production materials to products and thus confirms that the industrialization is an operational means through production processes (25,p385) The concept of industrialization was defined in accordance with the definition of the rich lexicon: as the state of establishment and development of industry in a country $(1, \mathrm{p} 113)$.

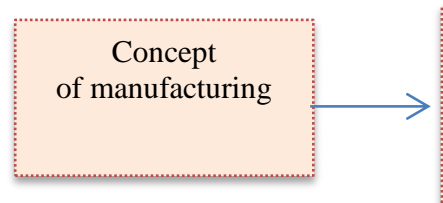

This process is known to produce unique and creative forms produced from curved and exotic shapes that cannot be produced in traditional forms these meet human needs and the process of industrialization is an essential process for the Renaissance and growth of societies for the increasing utilitarian, symbolic and aesthetic needs (fig. no.5 / Source Researcher)

\subsubsection{Manufacturing And Standardization:}

The standardization of the ages has been built to build human civilizations to serve the human being and to simplify the work it faces. It is a time when man teaches the use of a common language as well as standardized ways of writing to facilitate communication a new era has gone by the industry with science side by side in the path of social development the scientific basis for the production of the repetitive sentence, which has resulted in the need to pay attention to specific specifications and parameters of the materials, characteristics and dimensions of the different parts and components that comprise them. of goods and Machines so that the large production of a commodity can be subjected to a uniform system that ensures homogeneity $(22, \mathrm{p} 15)$ That is, standardization is an activity aimed at optimizing order in a given environment, by establishing conditions for common use and recurring taking into consideration actual and potential problems, including, in particular, the formulation, issuance and application of specifications, it also turns out that this standardization and symmetry in the design and manufacture of the types of pieces and parts leads to the facilitation of the industry, and thus interest in applying the method of what they call standardization, whether it includes standards, specifications or standardization of production methods and Others to suit the needs of use. (20,p 78 ).

\subsubsection{Manufacturing And Design:}

The architecture evolved with the development of manufacturing and its products and its methods varied with the multiplicity and variety of construction methods, the architecture is closely related to life. It is only the outcome of several factors that interfere with passion, culture and the spirit that prevails in the era. We note that architecture changes and evolves according to human needs, As shown in the table (1) below:

Table no. 1 show (Relationship between needs, architecture and purpose)

\begin{tabular}{|l|l|l|}
\hline The Need & Need And Shape & Objective And Purpose \\
\hline $\begin{array}{l}\text { Architecture for } \\
\text { Worship }\end{array}$ & $\begin{array}{l}\text { The need for worship has contributed to the creation } \\
\text { of new types of civilian buildings, in which they often } \\
\text { express the spirit of religion which gives nobility and } \\
\text { grace to stereotypes that do not fade in beauty, such as } \\
\text { the Temple of Abi Sinbel and the Church of Sofia } \\
\text { August (19 } 20)\end{array}$ & $\begin{array}{l}\text { The need for living( His } \\
\text { behavior within the space } \\
\text { environment) }\end{array}$ \\
\hline
\end{tabular}




\begin{tabular}{|l|l|l|}
\hline Architecture for Living & $\begin{array}{l}\text { The architecture for a living is now beginning to take } \\
\text { on more economical forms, such as public housing } \\
\text { and housing complexes, which are what the world's } \\
\text { population increases call for when the earth does not } \\
\text { fit or the material potential increases (19p21) }\end{array}$ & $\begin{array}{l}\text { The need for worship ( } \\
\text { Humanitarian needs) }\end{array}$ \\
\hline $\begin{array}{l}\text { Architecture for } \\
\text { production }\end{array}$ & $\begin{array}{l}\text { The architecture for production is the most important } \\
\text { pattern of architecture that has evolved in the world, } \\
\text { and the factories were the first to be inside the houses, } \\
\text { however, the Industrial Revolution necessitated its } \\
\text { construction and adaptation to service production, } \\
\text { such as the Helwan iron and steel complex.(20 p13) }\end{array}$ & $\begin{array}{l}\text { Formulation of architectural } \\
\text { forms) }\end{array}$ \\
\hline $\begin{array}{l}\text { Architecture for } \\
\text { Governance }\end{array}$ & $\begin{array}{l}\text { The buildings of the Kremlin in the former Soviet } \\
\text { Union, the White House of the United States of } \\
\text { America and the United Nations building are } \\
\text { witnessing the attachment of architecture to political } \\
\text { rule, the best testimony }\end{array}$ & Affect human behavior) \\
\hline $\begin{array}{l}\text { Architecture } \\
\text { services }\end{array}$ & $\begin{array}{l}\text { There are many forms of architecture in these areas to } \\
\text { serve their respective requirements. The design of the } \\
\text { hospitals differs from schools and classrooms, and } \\
\text { these are also for they are clearly distinguished from } \\
\text { the cinemas, theater and listening halls just as they are } \\
\text { featuring the places of play and terraces (21 p22) }\end{array}$ & $\begin{array}{l}\text { The need for Services( Affect } \\
\text { human behavior) }\end{array}$ \\
\hline
\end{tabular}

It's noted that architecture is a reflection of human needs over time, which has created a balance between the demands of the times and the demands of increasing human need over time and have been reflected in human behavior and form the basis of their behavior in the spatial environment in which they exist and these needs can be identified in terms of their impact on human behavior.

3.2 Stages of The Evolution of The Architecture Over Time Influenced By The Manufacturing Materials:

the relationship between manufacturing techniques and shape in architecture: Oast Shazier says that form formation is a natural result of the types of techniques used and that any formation is a method of creation and it considers technology to be responsible for all form relationships, such as proportionality and scale, regulation and spatial distribution or talk about the modern theory of production indicating the relationship of the architectural form directly to the standard specifications of the product and its function, that the technique creates the form and that not having to resort to change of shape according to technological methods The available technology makes a way to meet the functional and expressive requirements at one time through the final form (26,p67).

The Stone Age (before 2 million years) is the cornerstone of the primitive Stone Age, with a huge stone or wood, and the goal was to shelter and protect the inhabitants of aggression, and besides the stone and wood the mud (milk) and grilled clay (pay) were featured. (28,p10), Caves and caverns (for the protection of natural externalities and predators) humans have resorted to the materials of nature to provide shelter, build tents using primitive manufacturing materials and assemble in the form of tribes resulting from social need.
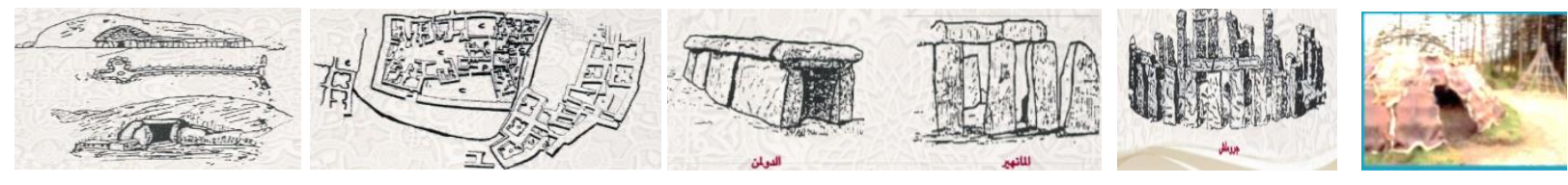

(fig. No.6) stone age (28,p23)

The emergence of civilizations (in the middie of the 18 th century) started it in the first buildings in ancient Egypt and Mesopotamia, and featured styles and architectural models which carries a special and aesthetic identity, the roofs in the primitive architecture were flat or more like domes, and the material was these roofs are twigs and clay and to carry roofs the poles were a mandatory structural element, turning to the element of beauty gathered the genius of architecture in the design then the dome of the domes evolved, becoming circular from the milk or roast, or from the stone. The development of the buildings, contracts and arches was also the same. (29,p 34), Since the beginning of history, architecture has become an art and science, requiring engineering study and aesthetic attention, which began in the first buildings in ancient Egypt and Mesopotamia, methods and architectural models have emerged that carry a special distinctive and aesthetic identity. 

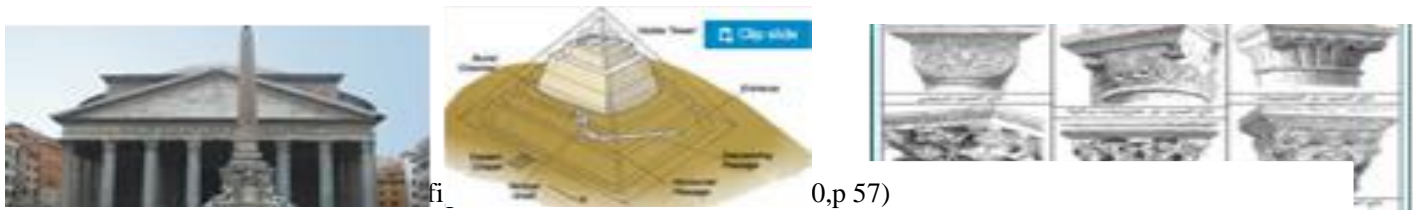

The modern arcnitecture (in the late or the Ir th century) that led to the city's own character, wnich led to the resurgence of the revolution of nature and the attempt to find appropriate solutions. A post-modern architecture has emerged to get rid of boring and monotonous interfaces in the formulation of architectural elements. and an attempt to form architectural components linked to a strong relationship that is expressive of the vocabulary of the past and consists of the contemporary situation and reads the positive of the future in addition to wanting to make the architectural elements more open, the objectives of a post-modernist architecture have been characterized by unity and characteristics of the post-modern architecture that it allows its objectives to be applied in different ways such as the embodiment of meanings and pluralism. (10,p10)
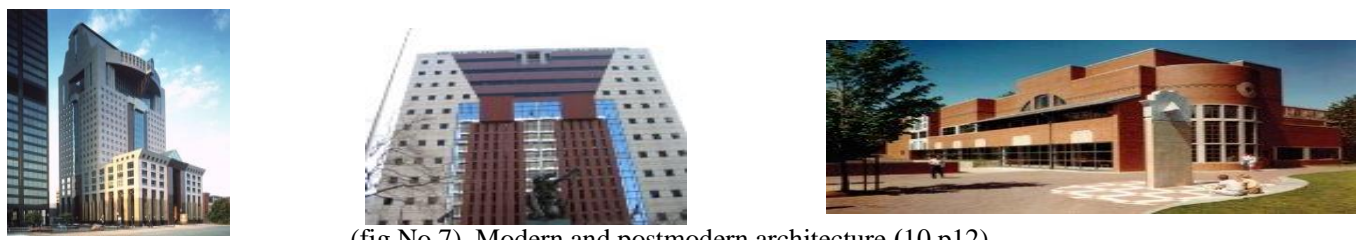

(fig No.7) Modern and postmodern architecture (10,p12)

Deconstruction architecture (in the late of the 20 th century) where this movement never believes in the traditional geometric shapes espoused by Euclid theories, where the architectural architecture is designed to fundamentally alter the concepts of architecture under the traditional form of lines. The upright and orthogonal of the architectural space to an abstract creative space depends on the forms of architectural lines except the traditional one to reach new architectural productions that are strong, hegemonic, dazzling and unilateral .( 12,p54)
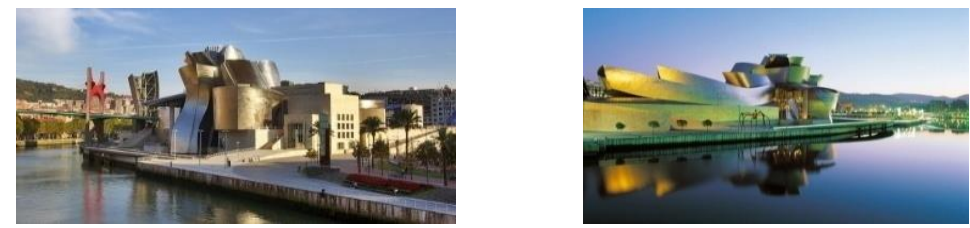

(fig. No. 8) Deconstruction architecture (19,p45)

The folding architecture (1966) relies on its ideas to reconfigure the architectural language and its projects are three dimensions of the chart is just one point to consider, the power and complexity cannot be realized actual space without changing the point of your vision to it thus, folding becomes the means by which a heterogeneous homogenous homogeneous surface can become, however, continuous (35).

In the twenty-first century, the human being lives in a dynamic and potentially complex reality, where the requirements of life and human desires have increased and the machinery industry is complicated and has become it's hard to live in this world, and it's easy for us to do it. The digital revolution, and thus the dreams are closer to reality and the emergence of virtual reality, digital handling with data and the phenomenal speed of processing and development of software where the designer's imagination was confined to the paper and the pen and the day became liberal in addition to the trend towards the Nonlinearity, determinism and imperfection and the appearance of the theories of chaos and disaster and quantum theories and the principle of probability and scientific extrapolation all of these factors are reflected in the building and the complex and shell forms have emerged (23,p14).

It is noted from the foregoing that the formal features reflect the type of material or technique used in the production of forms, because the composition of the form represents the types of technique used and expresses the method of creation, depending on the technological potential that turns ideas to a concrete material and conveys meaning to others, either technological methods meet the functional, utilitarian, aesthetic and environmental requirements through the form and according to the order of the building blocks that you specify, then the technique creates the shape. 


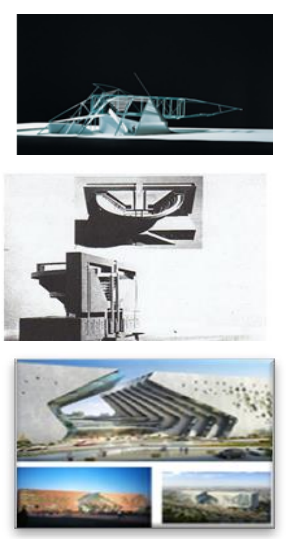

A project with the Venice Biennale of the design of Fenier Dae-Leoni 1985, a building that is in keeping with modern and sophisticated structural technology, looking forward to the twenty-first generation.

The open dwelling of the work of the Kobe Hemmelabbawi group 1983 shows how we should think, design and build in a rapidly evolving world that does not want closed house or closed street or closed thinking

The winning design of the new Palace of Culture in Basra note the high technology for architectural form formation

(fig. No.9) The evolution of architecture over time (33)

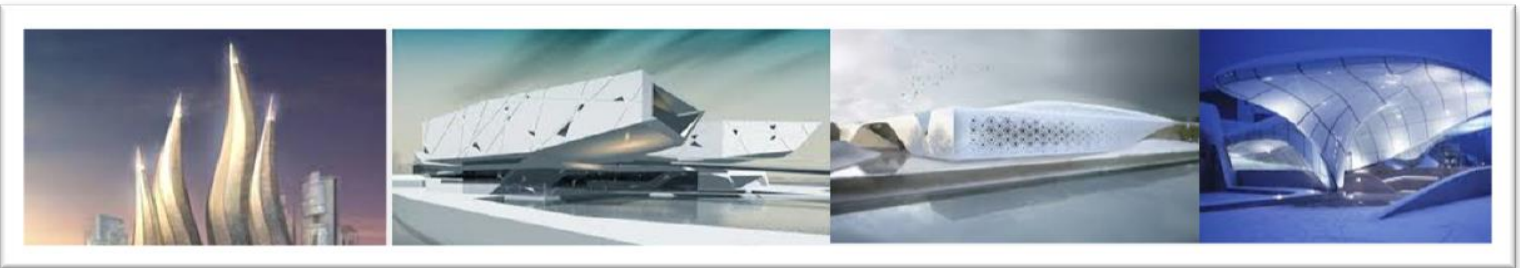

(fig. No. 10) Nanotechnology and architectural configuration in terms of the production of digital forms with high technology and advanced methods of Creation (34)

From the foregoing it is observed that the human being is the creator of the philosophy of the forms which is the originator and the one who is sensitive to its physical dimensions and which is affected by the inheritance and the facts that human beings have always been on the basis of the physical organization of the ocean with the aim of striking a balance between their basic needs as a living organism, environmental factors and economic structure, the need to control behavior and social communication and the development of industrialization helped it to meet those human needs is the one who always uses architecture and never and wherever he travels, he lives in space, sleeps in space, eats, keeps and interacts. With others, Earth representatives to shape the relations and interactions that create the occupants of space.

\section{1 LITERATURE REVIEW :}

The impact of industrialization is manifested in the sweep of the power of traditional forms across the timeline of the architecture, where the formulations have been influenced by different forms of developments in the field of industrialization. Manufacturing technology is the framework that complements these architectural patterns and since the beginning of the twentieth century science has become the basic engine of human life and its future. , in the light of the successive developments of the third millennium and its successive scientific revolutions, the architectural landscape has shown many positive consequences of those developments that have affected and opened up unprecedented prospects in the construction industry. The so-called digital gene, which created an unprecedented innovation revolution in architecture, and changed the path of architecture with its products in the shadow of computer integration and Stay away from forms of architectural innovation and industrialization are integrated with all scientific systems of electronics. Recently, the digital and social revolution represents a conceptual non-time-bound paradigm shift that is accompanied by a comprehensive change in all the concepts that are governing and inherited. A similar evolution in creative thinking is required by the recruitment of the architecture of the digital revolution because architecture is the place where all life variables that affect society where all axes are fused and reflect on the shapes. therefore those technical systems are targeted in structural contexts in all dimensions of the design and operational process and without a doubt, it's the central element in the process of architectural innovation, which affects the crystallization of architectural thought when excretion to those structural systems.. As a result, 
architectural thinking acquires innovative, creative and modern ideas that will meet the different needs of both the design process and societal requirements and reflect the possibilities of the temporal period and then elevate societal thought, which sometimes maintains creative dialogue with the capabilities of the imaginary designer, giving it new tools and terminology from the creation of the digital revolution that affects society and its culture. and therefore on the architectural product so that our societies will have scientific dominance through previous studies, After review of previous submissions (Abeer Sami 2013-Asma Magdy 2011-Mosawi 2010-Haydar Adnan 2015 -The Hill 2016Nuati Christian Norberg Schulz 2009-Branco 2011-Afifi and Ja'afari 2013)2 2

Table (2) shows the most important knowledge presented in previous studies:-

\begin{tabular}{|c|c|}
\hline Name of study & Knowledge \\
\hline \multicolumn{2}{|l|}{ International Studies } \\
\hline $\begin{array}{l}\text { Nuati Christian Norberg } \\
\text { Schulz } 2009\end{array}$ & $\begin{array}{l}\text { The influence of society in the production of architecture } \\
\text { The relationship between industrial technical systems and structural contexts in all } \\
\text { dimensions of the design process }\end{array}$ \\
\hline Branco 2011 & $\begin{array}{l}\text { Architectural intellectual creativity in meeting human needs } \\
\text { Give the architecture innovative ideas innovative using modern construction systems }\end{array}$ \\
\hline The Hill 2016 & $\begin{array}{l}\text { The integration of the architectural formula through the employment of manufacturing } \\
\text { in architecture and the digital revolution } \\
\text { Architecture has become a place that brings together different fields that affect society } \\
\text { and its behavior }\end{array}$ \\
\hline \multicolumn{2}{|l|}{ Local studies } \\
\hline Abeer Sami 2013 & $\begin{array}{l}\text { The relationship between manufacturing and architectural form over time and different } \\
\text { architectural movements } \\
\text { The formulation of the shape was influenced by the architectural technique }\end{array}$ \\
\hline Asma Magdy 2011 & $\begin{array}{l}\text { The relationship between technological development and industrialization and its } \\
\text { accumulation in the manufacture of architectural patterns } \\
\text { Positive development in the industry produced new architectural styles }\end{array}$ \\
\hline Mosawi 2010 & $\begin{array}{l}\text { The emergence of the digital gene has produced an innovative and distinctive } \\
\text { architecture that has shaped the form } \\
\text { Integrating the computer into the design process and moving away from traditional } \\
\text { shapes }\end{array}$ \\
\hline Haydar Adnan 2015 & $\begin{array}{l}\text { Transition through time through concepts and change in thought inherited in } \\
\text { architecture } \\
\text { Similar development in creative architectural thought }\end{array}$ \\
\hline Afifi and Ja'afari 2013 & $\begin{array}{l}\text { The relationship between the imaginative designer's ability and the digital revolution to } \\
\text { change the human needs affecting the production and control of architectural forms }\end{array}$ \\
\hline
\end{tabular}

Through previous studies, the vocabulary of the theoretical framework can be derived as shown in the table below (Table 3):

\begin{tabular}{|c|c|c|}
\hline Main vocabulary & Secondary vocabulary & Possible value of measurement \\
\hline \multirow[t]{12}{*}{ Architectural Patterns and types } & \multirow[t]{4}{*}{ Traditional pattern } & Proportionality \\
\hline & & Regulation \\
\hline & & Specific scale \\
\hline & & Specific space distribution \\
\hline & \multirow{4}{*}{$\begin{array}{l}\text { Measured format (quantitative } \\
\text { production) }\end{array}$} & A recurring type at all levels \\
\hline & & Standard specifications \\
\hline & & Functional type \\
\hline & & Formal change \\
\hline & \multirow{4}{*}{ Creative technical pattern } & Perform the function \\
\hline & & Perform Expressive side \\
\hline & & Creating Creative Forms \\
\hline & & Part-level recurring type \\
\hline \multirow[t]{2}{*}{ Industrial Technology } & \multirow[t]{2}{*}{ Traditional manufacturing } & Clarity \\
\hline & & The Simplicity \\
\hline
\end{tabular}

\footnotetext{
${ }^{2}$ For more enlightenment see the sources as the shortening of the proposal to fit the number of search pages.
} 


\begin{tabular}{|c|c|c|}
\hline & & Expression of the prevailing age \\
\hline & & perform the need \\
\hline & \multirow[t]{4}{*}{ Unique manufacturing } & Contrary to traditional \\
\hline & & Change \\
\hline & & Architectural Creativity \\
\hline & & Strong \\
\hline & \multirow{7}{*}{ quantitative production } & Domination \\
\hline & & The dazzling \\
\hline & & the uniqueness \\
\hline & & Recurring types \\
\hline & & The Simplicity \\
\hline & & Recurring buildings \\
\hline & & $\begin{array}{l}\text { Homogeneous forms with a formal module } \\
\text { (common system) }\end{array}$ \\
\hline \multirow[t]{10}{*}{ Creative manufacturing } & \multirow{4}{*}{$\begin{array}{l}\text { creativity of Technical } \\
\text { technological } \\
\text { Configurable creativity }\end{array}$} & Innovative form Creativity \\
\hline & & $\begin{array}{l}\text { Satisfying aesthetic and symbolic } \\
\text { utilitarian needs }\end{array}$ \\
\hline & & Promoting community thought \\
\hline & & Formal creativity \\
\hline & \multirow{6}{*}{ Intellectual creativity } & Stay away from tradition. \\
\hline & & Integration of architectural systems \\
\hline & & Intellectual displacement \\
\hline & & $\begin{array}{l}\text { A comprehensive change of inherited } \\
\text { concepts }\end{array}$ \\
\hline & & International identity \\
\hline & & $\begin{array}{l}\text { Creative dialogue between designer and } \\
\text { receiver }\end{array}$ \\
\hline
\end{tabular}

\section{5- APPLICATION:}

After it has been manufacturing indicators are extracted for architectural shapes, they are applied according to the vocabulary on elected samples to arrive at the considerations and impact lines that can be adopted and utilized in subsequent productions. Accordingly, five samples were elected at different time periods, using digital manufacturing and modeling in the production and design of architectural forms around the world and in order to achieve the broadest possible comprehensiveness, the election was carried out in accordance with the following considerations:

-The formal diversity of the alphabet.

- Creativity in the production of architectural forms.

-Use manufacturing processes and modeling in their production.

-Projects that have developed their ideas in the field of architecture.

-Projects aroused the interest of the architectural center Based on the foregoing.

5.1 project 1: Sydney Opera House- Joon Otzon-1973

The Opera house was built on a part of Sydney and is a rocky base with very limited space, Its elements were manufactured in a pre-fabricated laboratory where it came up with the idea of making all the shells or external structures in a uniform and in both directions, this solution allowed for uneven lengths

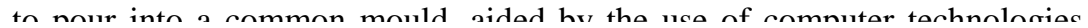

5.2 Project2: the Guggenheim Museum of Bilbao in Spain-famous Frank Jerry-1997

The Guggenheim Museum of unexpected geometric links, it is composed of precise, complex and curved walls as well as vast viewing areas to achieve both things, the walls had to be thin, which led to the problem of ensuring that the building was sufficiently strong to support itself, where the cement would work, but the walls would be very thick, so a thin metal structure was used in the form of double and clear curves for building reinforcement, which complicated the features of

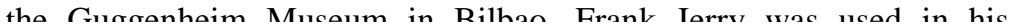

5.3 Project 3: Arts and Music Center-Abu Dhabi - Zaha Hadid-2018

Project idea: The building block is very fast from the island's depth to the sea and appears to be fast as a ship that it wishes to launch without being caught. The composition Aesthetic and Disassembbezme suggests a great disguise to the culture of the sea and consists in a symbolically interesting form of a contemporary ship with its techniques and body natches. The desion of the iron for the theatre and Arts Honse reflects the
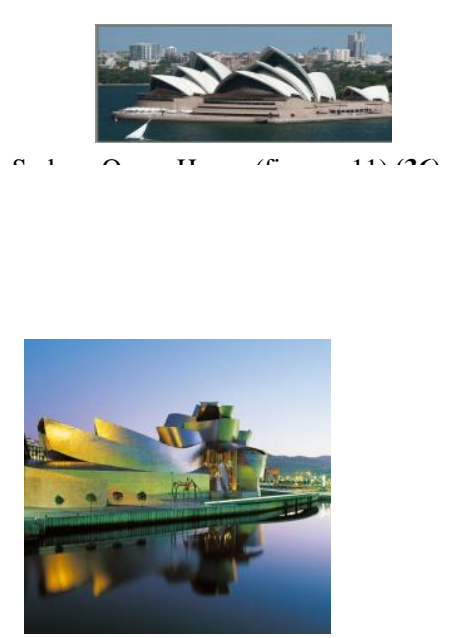

The Guggenheim Museum (fig. no12)

(22)

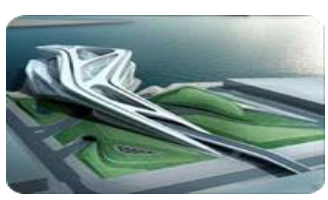

Arts and Music Center (fig. no. 13) (7) 
5.4 Project 4: Marseille housing Unit - France-Architecture Lokubuzia-1952 While designing his study of the Soviet Joint housing project "City within the city", the architect adopted the same design for what he considered to be the virtuous city in four more buildings. The building of Marseille Housing Unit between 1947 and 1952, constructed from cement, was built on the cost of the steel tyre, which was larger than the post-war budget ambitions. The building contains 337 apartment houses on 12 floors. They also include shops and an architectural bookshop, babysitting, educational events, a doctor, a gym, a public hotel and a

5.5 Project 5: Parc de la Lette largest French parks-Bernard Chumi 1982

It has an area of 55.5 hectares and exercises a multidisciplinary program: Contemporary circus concerts, exhibitions, theatre, dance and outdoor cinema festivals. Many of the 26 red buildings in the garden are littered with a well-known architectural designed to decorate and decoration, offering many services such as nurseries, cafes and workshops. The garden is divided into two parts, and for contact with them there are two

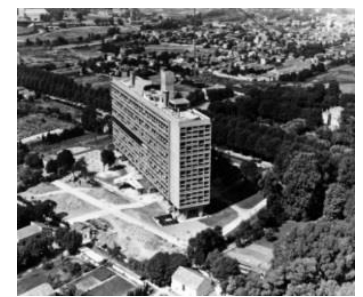

Marseille housing Unit (fig. no. 14) (37)

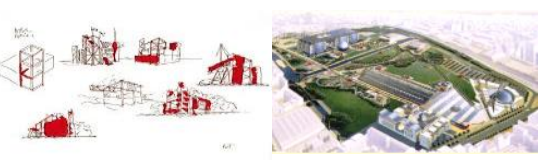

Parc de la Lette (fig. no. 15) (18) types of pedestrian bridges $(18, \mathrm{p} 19)$

\section{6-RESULTS:}

This section includes the determination of the method of measuring the set of variables at the levels related to the theoretical framework. The method of measuring the analytical descriptive measurement based on the direct reference on the table according to the selected samples, Check if values are recorded on the variables table,The data are analyzed in this case by calculating the percentage of each variable according to the statistical equation in the calculation of ratios:

$\mathrm{Mi}=(\mathrm{xi} /$ sum $\mathrm{xi}) * 100$

The variable can be a key by the number of signals it receives, which determines the percentage value if it indicates:

- Be a major when you get a percentage $(50 \%-100 \%)$.

- Be artificial when you get a percentage $(0 \%-49 \%)$.

Apply the theoretical framework vocabulary to the set of elected projects to derive the most important results:

The values in the table represent: 1 partially realized 0.50 unrealized

Table no 3 show Application of Vocabulary

\begin{tabular}{|c|c|c|c|}
\hline \multirow[t]{2}{*}{ project } & \multicolumn{3}{|c|}{ Architectural Patterns and styles } \\
\hline & Technical pattern & Standardized format & Traditional pattern \\
\hline Sydney Opera & 1 & 0.5 & 0 \\
\hline $\begin{array}{l}\text { The Museum of } \\
\text { Guggenheim }\end{array}$ & 1 & 0 & 0 \\
\hline Arts and Music Center & 0.5 & 0 & 0 \\
\hline $\begin{array}{l}\text { Marseille Accommodation } \\
\text { Unit }\end{array}$ & 0 & 1 & 1 \\
\hline Parc de la Lette & 0 & 1 & 0.5 \\
\hline \multirow[t]{2}{*}{ project } & \multicolumn{3}{|c|}{ Industrial Technology } \\
\hline & $\begin{array}{l}\text { Manufacturing } \\
\text { measured }\end{array}$ & $\begin{array}{l}\text { Uniquely Creative } \\
\text { Manufacturing }\end{array}$ & $\begin{array}{l}\text { Traditional } \\
\text { manufacturing }\end{array}$ \\
\hline Sydney Opera & 0 & 1 & 1 \\
\hline $\begin{array}{l}\text { The Museum of } \\
\text { Guggenheim }\end{array}$ & 0 & 1 & 0 \\
\hline Arts and Music Center & 0 & 1 & 0 \\
\hline $\begin{array}{l}\text { Marseille Accommodation } \\
\text { Unit }\end{array}$ & 1 & 0 & 1 \\
\hline Parc de la Lette & 0.5 & 0 & 1 \\
\hline project & \multicolumn{3}{|c|}{ Creative manufacturing } \\
\hline
\end{tabular}




\begin{tabular}{|l|l|l|l|}
\hline & Intellectual creativity & Creative Technology & Configurable creativity \\
\hline Sydney Opera & 1 & 1 & 1 \\
\hline $\begin{array}{l}\text { The Museum of } \\
\text { Guggenheim }\end{array}$ & 1 & 1 & 1 \\
\hline Arts and Music Center & 1 & 1 & 1 \\
\hline $\begin{array}{l}\text { Marseille Accommodation } \\
\text { Unit }\end{array}$ & 0 & 0 & 0 \\
\hline Parc de la Lette & 0.5 & 0 & 0.5 \\
\hline
\end{tabular}

It can be noted from the above application that the patterns, architectural, creative manufacturing and industrial technology change with time and with the different quality of the building and the reason for which it was built. The Marseille housing project is a model for quantitative production The level of the total wells succeeded in filling the shortage by $66 \%$ in the housing units and the argument in the functional aspect and failure in the non-exclusivity Creativity and the creation of creative forms of global identity, a self-investigating identity that lacks the creative aspect as opposed to the measurement And repetition in the project Sydney Opera where the repetition was at the level of the single building thus achieved creativity and uniqueness And the global identity is $100 \%$ where it is noted that the repetition at the level of buildings achieve boredom and quantitative repetition non-creative as opposed to The repetition of industrialization at the level of parts achieved creativity and uniqueness as industrial and technological development helped to produce forms Creative at the level of using computer modeling and digital genetics for example, in the Arts Center project 33\% music and museum Guggenheim noted that the process of manufacturing had negative aspects on the level of quantitative repetition of buildings and a positive side Represented by creativity and the sweep of the power of traditional forms and uniqueness in the creation of forms with meanings of form and intellectual dazzling .

7- FINAL CONCLUSIONS:

- Manufacturing failed in modern architecture in its reliance on profiling and repetition at the level of the whole, producing frequent patterns of boredom lacking creativity Despite the need for form , in contrast to manufacturing used in the architecture of disassembly or folding architecture and modern movements such as mobile, ecological and digital architecture and others achieved creativity and uniqueness in its productions global identity investigator.

- Quantitative production process is achieved according to the project function and its impact, Note that the residential projects, the process of repetition led to the production of boredom and self-identity investigator is missing the global identity, unlike the repetition at the level of parts and within the same project achieved creativity and uniqueness (Need for self-realization) .

- Modern architecture projects were relying on quantitative production to perform the need after the World War, where we needed to fill the shortfall, lost the creative side and moved away from the identity and privacy of the societies and postmodern architecture maintained the traditional forms. The quantitative production of manufacturing did not destroy the traditional forms, Deconstruction and folding architecture that came in unusual and creative ways and represented a paradigm shift and intellectual design process

- The industrialization revolution has made tremendous potential in helping to implement the shape with modern technologies and systems, which has made architectural design a creative and unobstructed process, It opened up new Horizons for the architect to launch and innovate and produced unprecedented architectural formations using the latest technology (Need for appreciation).

- Relying on industrialization and its modern methods of architectural design processes is one manifestation of technological development, leading to speed and accuracy in performance and implementation, and access to unprecedented structural formulations.

- As a result of technological and technical development, new architects will have extensive experience as a result of cohabitation, wandering within building spaces and correcting design errors.

- The architect is a part of the surrounding environment that interacts with it and integrates with it with its renewable and differentiated data in the context of the systems and proposals of the times, It is imperative that it react positively to what the flag does not ignore and denounce, but on the contrary it must provide its society with its needs and realistic requirements in a conscious developmental manner.

8- RECOMMENDATIONS:

-Architects need to take advantage of the evolution in all areas of science and innovation in architectural work.

-Attention from manufacturing as a design tool to enhance the process of all phases. 
-The need to establish workshops to discuss technical developments and their impact on design, while scientific research should be guided in the work of studies to select and employ technologies developed in accordance with the circumstances, potentials and requirements of society.

-View international competition in the post-globalization and architectural competition with States.

-Invite the students of architecture to return to traditional forms and adopt them in contemporary construction.

\section{REFERENCES:}

[1] A. G. ,Abu Al Azm, The Rich Collector - 113,111.

[2] P., Admine, "Fourth Place The Platonistic Five Objects",2012, Algeria University.

[3] H . m. Afifi, and z.a. Al-Jaafari, , "Advanced Digital Manufacturing In Architecture Authors",2011, Ain Shams University, Egypt.

[4] M. m. Ahmed, "The concept Of Manufacturing" ,2016, article.

[5] R. s. Al Tal ," The Impact of Modern Architectural Trends on the Mosque Form", 2016, German Jordanian University, Amman-Jordan

[6] M. a. Al-Hantoush,"The Philosophy of Islamic Beauty and its Relation with the Sinography of the Presentation at the Safa Brothers",2012, Research Publication , Cairo University.

[7] M. t . AlNaim, " Amazing Building for the New Century" ,2013, AlBina Magazine Article.

[8] A. k. AlSayed, "Analysis of the theory of needs ", 2011, article published.

[9] A. s. Bahamam, "Manufacturing Systems", 2012,King Saud University,Research Published.

[10]A. b. Bahnasi ,"Building Modernity and Post Modernism",1997, Research publication,University of Tanta.

[11]N. s. Christian," Foundations of Modern Architecture" ,2013, King Abdulaziz University, Saudi Arabia .

[12]A.Dina , "Building Technology between the dimensions of the present and visions of the future",2013, published research,Tanta University

[13]A. m. Fadel, "Smart Architecture and its Technological Reflection on Design", 2011, Assiut University.

[14]N.h. Hassan," Brothers purity and the theory of evolution" ,2011,Philosophy and thought, Egypt.

[15]H. a. Hossi,Architecture and the rings of development throughout history,2010, Book .

[16]Ibn Manzoor, "The Arabic Sanctuary,1970, Boulaq edition, Cairo

[17] Intermediate Dictionary, Arabic Language Complex",2004, page 171,Cairo.

[18]jaky tina ,"Parc de la Villette Address",2017,Paris, France.

[19]A.H. Khafaji, "The impact of digital manufacturing in contemporary architecture", 2015,University of Technology , Baghdad.

[20]B. Kolarevic, "Designing And Manufacturing Architure In The Digital Age",2016 ,university of Pennsylvania-usa.

[21]M.i. Mahmud, "Book of the End of Myth Ibn Khaldun's Theories quoted from the letters of the brothers Safa,Dar Qabaa For publication", 2009,Cairo.

[22]S.m. Mohamed, "History of architecture and late architecture - the stream of deconstruction architecture and advanced architecture"2011, University of Palestine.

[23]A.s. Saeed," Digital technology and their application in organic origin structures",2015, University of Baghdad.

[24]A. a. Sami, " Architecture after the digital revolution",2013, University of Qahtara, Egypt.

[25]Turquoise, Glory of religion, Dictionary Ocean1003, page 131-2000.

[26] A.a. Wiss," The Impact of Technology on Architectural Design",2010,published research , University of Palestine.

[27]J.y. Yapah, "Principles of Architecture",2010, Published article.

[28] W. y.Youssef,"Lectures of the history of architecture in the Department of Architecture",2000, University of Alexandria.

[29]Z. m. Yusufi, "Architecture in the Stone Age and the Mediator and modern",2011 , article published.

[30]https://ar.wikipedia.org/wiki/.

[31]http://www.al-malekh.com/vb/f451/15282

[32] http://artsyap.blogspot.com.

[33] https://www.al-mashahir.com.

[34]http://www.arch-news.net/2013

[35] https://www.al-mashahir.com.

[36]https://www.blogger.com.

[37] http://www.arch-news.net/2013-11-01-22-50-55/2013-12-19-09-48-03/item/33156-2014-04-08-18-05-42/33156-201404-08-18-05-42\#.WZc7w_gjHI 